This is an Accepted Manuscript of an article published by Springer in Vocations and Learning on 15/3/17, available online: $\underline{\text { http://rdcu.be/p8vM }}$

To cite this article: Palesy, D (2017): Learning in the absence of direct supervision: Person-dependent scaffolding , Vocations and Learning, DOI 10.1007/s12186-017-9176-9

\title{
Learning in the absence of direct supervision: Person-dependent scaffolding
}

\author{
Abstract \\ Contemporary accounts of learning emphasise the importance of immediate social partners such as \\ teachers and co-workers. Yet, much of our learning for work occurs without such experts. This paper \\ provides an understanding of how and why new home care workers use scaffolding to learn and enact \\ safe manual handling techniques in their workplaces, and suggests how their learning may be supported \\ in the absence of direct supervision. A qualitative approach was adopted for this inquiry, in which \\ newly recruited workers were directly observed and interviewed in their workplaces following \\ classroom training. When learning without direct supervision, these workers were found to use the \\ scaffolding in person-dependent ways. They constructed, engaged with, and subsequently dismantled \\ their scaffolding as personally required, rather than relying on their teacher to decide how and when \\ these forms of learning support should be used and withdrawn. Consequently, a range of scaffolds \\ should be provided in the workplaces of these individuals, without rigid stipulations about how and \\ when they are to be accessed. That is, the learners themselves should be encouraged to decide on the \\ type and frequency of their interaction with the scaffolding provided, and to access or withdraw this \\ support as required.
}

\section{Key words}

Workplace learning; home care workers; manual handling; scaffolding; person-dependence 


\section{Introduction}

This paper reports the findings from a small-scale Australian study that evaluated the effectiveness of a pre-determined scaffolding framework, implemented for a group of new home care workers (HCWs) who are required to apply manual handling knowledge to their workplaces (i.e., their clients' homes) following a single two-hour classroom training session. These workers do not have the close support and guidance of more experienced colleagues, as they carry out their work in the privacy of their clients' homes. Instead, they are expected to complete the (often novel and challenging) tasks that comprise this role after brief training, and in the absence of direct supervision.

Conceptually, this study is concerned with understanding the bases for learning and developing work-related knowledge in the absence of direct supervision. Vygotsky's (1978) socio-cultural account of learning, and in particular, his Zone of Proximal Development (ZPD), provides a useful theoretical framework for this understanding, in which an individual's learning is enhanced through the close guidance of a more skilful other who provides the appropriate tools and assistance to achieve the task. These kinds of supports have been more specifically termed 'scaffolding' in the work of Bruner (1975), and Wood, Bruner and Ross (1976). Once the individual, with the benefit of scaffolding, masters the task, the scaffolding can then be removed and the individual will then be able to complete the task again on their own (Brown \& Palincsar, 1989; Wertsch, 1985). This view reiterates the model of apprenticeship-style learning in social and situated contexts (Brown \& Palincsar, 1989).

Yet, while these accounts emphasise the contributions of the social world, HCWs are required to learn and enact their occupational practice in relative social isolation (i.e., in clients' private homes) and, indeed, many HCWs work safely and effectively without direct supervision. Consequently, there must be ways of learning the knowledge required for the role without direct supervision and support, premised on their individual agency and what is afforded by their social world (Billett, Ehrich \& 
Hernon-Tinning, 2003; Eteläpelto, Vähäsantanen, Hökkä, \& Paloniemi, 2013). Indeed, perhaps most of the learning we do across our working lives is of this kind.

Procedurally, understanding the kinds of learning and development support that most effectively assists HCWs to learn and work safely in clients' private homes is critical for the quality of support they provide to their clients, and also for their own health and wellbeing. Therefore, the research question that underpins this paper is: 'how' and 'why' does scaffolding facilitate manual handling competency for new HCWs, who work in the absence of direct supervision and support? While the focus is on HCWs of one home care organisation learning and enacting safe manual handling techniques, the proposals in this paper potentially extend to other elements of training for HCWs, and indeed, to many other groups of workers who conduct their practice without direct supervision or support.

\section{Working in Australian home care}

The home is setting of choice for an increasing number of frail older adults and people with disabilities who need long term care (Health \& Community Services Workforce Council, 2012). Paid HCWs provide the majority of this care, assisting with tasks of daily living such as mobilising, bathing, toileting, dressing, eating and general household duties. All of these tasks require a degree of 'manual handling, i.e., they may require the worker to lift, lower, push, pull, hold, carry, move or restrain an object, load or body part. Home care work, therefore, can be physically challenging (Stone, Sutton, Bryant, Adams \& Squillace, 2013), comprising a diverse set of activities that require the application of knowledge in different ways, purposes and circumstances in clients' private homes, all without direct supervision or support. 
The home care workforce predominantly consists of middle-aged females (Australian Institute of Health \& Welfare [AIHW], 2013), often from minority backgrounds (AIHW, 2009), with low levels of education and training (Hugo 2007; 2009; Martin \& Healy, 2010). These workers are usually employed on a casual or part-time basis, and earn below the average Australian wage (Australian Bureau of Statistics [ABS], 2014). Moreover, this demographic appears to be represented in other countries such as the US, (Markannen, Quinn, Galligan, Sama, Brouilette et al., 2014; Stone et al., 2013), the UK (Manthorpe \& Martineau, 2008), and some European countries (Boerma, Kroneman, Hutchinson \& Saltman, 2013).

The HCW role, consequently, is often undervalued (Stone, 2004). HCWs are perceived as poorly trained women with little more than mothering skills (Nay \& Garratt, 2002; Somerville, 2006), receiving low pay for menial work which might be considered as a 'labour of love' (Markkanen et al., 2014; Meagher, 2006; Stone, 2004). Job training and preparation frequently fails to prepare these workers for the provision home-based care, evidenced by their high rates of musculoskeletal injuries (predominantly back injuries), and poor retention rates (Mott, Chau \& Chan., 2007; Markannen et al., 2014; Meagher, 2006; Nay \& Garrett, 2002; Stone et al., 2013). In essence, HCWs are undervalued, poorly prepared for their roles, and receive negligible supervision and support on-the-job; factors that potentially impact on the recruitment, training and retention of staff (Stone et al., 2013).

\section{Learning home care work}

The term 'knowledge' is used in this paper in reference to the conceptual and procedural cognitive structures that are organised, interlinked and held in memory. These cognitive structures are engaged by individuals to achieve their learning goals, and are further extended and developed through this engagement (Yates \& Chandler, 1991). Conceptual, propositional or 'declarative' knowledge 
(Anderson, 1982), or knowledge 'that' (Ryle, 1949), comprises concepts, facts, assertions and propositions. For HCWs, manual handling training typically focuses on explicating conceptual knowledge of the human body and movement, e.g., anatomy and physiology, body mechanics, muscle recruitment (Palesy, 2015; Varcin-Coad, 2003). Procedural knowledge, or knowledge ‘how' (Ryle, 1949), comprises the knowledge that we need to 'do' things. In classrooms, new HCWs are often trained to consciously retrieve manual handling concepts and compile them into a series of simple movements or tasks, such as rolling a client in bed or pushing a wheelchair (Palesy, 2015). Together, these concepts and procedures are widely accepted as being central to the successful performance of safe and effective manual handling, or manual handling ‘competency’ (Palesy, 2015; Varcin-Coad, 2003).

While the usual distinction is between conceptual and procedural knowledge, or knowledge 'that' and knowledge 'how' respectively (Anderson, 1982; Ryle, 1949), it is proposed that these kinds of knowledge are inherently dispositional and may underpin how cognitive structures are deployed (Billett, 1997; Perkins, Jay, \& Tishman, 1993). So, there is interdependence between individual and social processes in learning and development (Wertsch, 1991), which are proposed as bases for knowing (Billett, 2001). Here, knowing is held to be an active and reciprocal process which brings together knowledge sets (i.e., conceptual, procedural) in engaging with the world beyond the physical self and internal processes of the mind (Billett, 2001). This process may have particular relevance for those who work without direct supervision or support.

Brief, induction classroom training sessions are a common method of orientating new workers to their roles, conveying knowledge such as safe lifting and back care (i.e., 'manual handling'). However, classroom manual handling training sessions have been largely unsuccessful in reducing the unacceptably high rates of musculoskeletal injuries amongst these workers (Faucett, Kang \& 
Newcomer, 2013; Markannen et al., 2014). While larger organisations may offer more systematic training programs, smaller agencies tend to provide more ad-hoc and fewer hours of training, citing financial constraints or workers 'already skilled enough' as reasons why this is the case (Baldock \& Mulligan, 2000). When training is offered as part of a HCW's orientation to an organisation, sessions are anywhere from 10 minutes to four hours in duration (Aylward, Stolee, Keat \& Johncox, 2003; Baldock \& Mulligan, 2000; Bernoth, 2009) and vary in format. For example, some HCWs attend brief classroom training followed by a period of supervised practice in the workplace of up to two weeks, others receive no formal induction training for their roles at all (Bernoth, 2009; Palesy, 2015). This perfunctory workplace preparation creates a unique set of challenges for HCWs as they seek to apply any training to the privacy and intimacy of a client's home, in the absence of direct supervision. Therefore, understanding the ways in which these workers engage with scaffolding in these circumstances, and understanding their motivations for this engagement, represents an important and worthwhile task.

\section{Conceptual framework for examining learning in the absence of direct supervision}

A central Vygotskyian concept is the ZPD, which is defined as the distance between what a learner can do with and without help (Vygotsky 1978), and is used to explain the social and collaborative nature of teaching and learning (Boblett, 2012; Verenikina, 2008). More specifically, the metaphor of 'scaffolding' provides the basis for examining workplace learning in this paper. Although never used by Vygotsky (Verenikina, 2008), the term 'scaffolding' was introduced by Bruner (1975), and Wood et al., (1976) as a practical application of Vygotsky’s ZPD concept (Boblett, 2012). In this sense, scaffolding is used to capture the nature of support and guidance in learning and development. Teachers and more knowledgeable others interact with the learner within the ZPD, scaffolding their 
learning and assisting them to meaningfully participate in, and perform tasks that are beyond their unassisted abilities (Belland, Drake \& Liu, 2011). While the metaphor of scaffolding was first proposed in the field of child psychology (Boblett, 2012), it has been applied to studies of workplace learning in adults, including teacher education (e.g., van Lier, 2008; Walqui, 2006), nursing (e.g., Salyers, Carter, Cairns \& Durrer, 2014), and online learning (e.g., Jumaat \& Tasir, 2014; Sharma \& Hannafin, 2007), particularly in relation to scaffold types and design. However, suggestions about what constitutes actual scaffolding are diverse, and in some ways scaffolding has become an umbrella term for any form of teacher support, without clear guidelines about how scaffolding should be used, or what drives learners' use of scaffolding (Belland et al., 2011; Hammond, 2002). Therefore, understanding how and why new workers use various scaffolding supports to learn the requirements for their occupational practice addresses a gap in this area.

For the purpose of this paper, 'scaffolding', and related scaffolding activities, is presented as a three-level system: (a) macro-scaffolding - the whole structure of the scaffold itself e.g., the training curriculum; (b) meso-scaffolding - the actual learning activities, including the ordering of learning experiences; and (c) micro-scaffolding - the moment-by-moment collaborative work of building the scaffold, including the interactions between the learner and others such as experts and peers (Boblett, 2012; van Lier, 2007, Walqui, 2006). Within this system, all levels operate concurrently, each interacting with and influencing the others. Yet, the ways in which the scaffolding activities in each level are provided to (or taken from) each learner is likely to be different, depending on their individual needs and circumstances. Therefore, scaffolding might be viewed as a kind of 'wildcard' i.e., it represents any number of activities whose quality and influence is unpredictable and person-dependent.

Further to this three-level system, Van Lier (2004) identifies four sources of scaffolding for the learner which may be applied to HCWs who work in relative social isolation: (a) the expert; (b) HCWs 
at the same learning level; (c) HCWs (or others) at a lower level - where assisting or orientating them to the role requires them to organise their own thoughts; and (d) working alone - which requires HCWs to draw upon their inner resources and experimentation e.g., organising the client's daily living activities, deciding on the best way to persuade a client with dementia to have a bath. The suggestion is that these sources are made available to the learner based on their specific needs (van Lier, 2000). Such a view emphasises the importance of individual agency (i.e., the learner's own voice and initiative) when engaging with scaffolding to learn and apply new knowledge (Boblett, 2012; Valsiner \& van de Veer, 2000; van Lier, 2000), such as that required for an occupational role. In these circumstances, person-dependent factors, such as the learners' own personal interests and goals, may influence how and why individuals learn through engagements with scaffolding (Billett \& Pavlova, 2005; Collin, Paloniemi, Virtanen \& Eteläpelto, 2008; Eteläpelto et al., 2013).

This person-dependence suggests learners' use of scaffolding may be unpredictable and unplanned (Boblett, 2012), and therefore organisations should not be rigid about the type of scaffolding provided for their workplace learners. Indeed, Daniels (2016) strongly advises against a rigid set of scaffolds, as this negates the collaborative nature of learning within the ZPD. The risk is that when teachers construct scaffolding and present it to their students, learning becomes a one-way process, where the teacher constructs the scaffold and imposes it on the learner. So, for HCWs learning in the absence of direct supervision and support, it may be helpful to provide a number of supports in the scaffold, yet acknowledge the person-dependence of each novice worker and concede that they may not use them in the same ways as others. Moreover, understanding how and why HCWs use these scaffolding supports when learning in the absence of direct supervision may advance contemporary accounts of workplace learning. 


\section{Scaffolding the learning of $\mathrm{HCWs}$}

What distinguishes scaffolding from other forms of teaching and learning has been considered by a number of researchers over the years (e.g., Amerian \& Mehri, 2014; Hammond, 2002; Mercer, 1994). However, what is most useful for this study is the early work of Mercer (1994), who proposed a number of criteria for scaffolding: (a) focus is on learning a specific concept or task; (b) learners could not succeed without intervention; (c) the aim is for some new level of competence on the learner's part; (d) there must be evidence of learners successfully completing the particular task at hand; and (e) there must also be evidence that learners are able to go on to independently deal with subsequent related tasks or problems. As the aim for new HCWs is to learn specific manual handling techniques and apply these to a number of other tasks in the various circumstances of clients' private homes, these criteria may be readily applied to HCWs' learning in the absence of direct supervision.

A separate but related study explored the existing manual handling training situation for a group of HCWs and then proposed a four-phase scaffolding framework, designed to enhance HCWs' learning and better prepare them for their socially-isolated roles (Palesy, 2015). An outline of the scaffolding, along with the proposed interventions, can be found in Table 1. The left-hand column outlines each phase of the framework. The second left column lists the specific scaffolds offered to the HCWs, and the next column identifies the source of the scaffolding according to van Lier $(2000,2004)$. The right-hand column provides a justification for inclusion of each scaffold, in line with Mercer's (1994) criteria for what constitutes scaffolding. 
Table 1: Scaffolding framework for new HCWs

\begin{tabular}{|c|c|c|c|}
\hline Phase & Scaffolds offered & Source & Justification \\
\hline $\begin{array}{l}\text { One: } 0 \text { weeks: } \\
\text { Initial classroom } \\
\text { training }\end{array}$ & $\begin{array}{l}\text { Peer interaction - small group work and practical activities } \\
\text { Written materials - organisational policies and procedures, } \\
\text { classroom training handout } \\
\text { Manual handling concepts and procedures conveyed and } \\
\text { demonstrated by trainer, service coordinator, experienced } \\
\text { HCW preceptors } \\
\text { HCWs observed by trainer for a new level of proficiency and } \\
\text { marked off against checklist }\end{array}$ & $\begin{array}{l}\text { Experts } \\
\text { HCWs at same } \\
\text { learning level }\end{array}$ & $\begin{array}{l}\text { Learners aiming for new level of competence } \\
\text { Learners require intervention } \\
\text { Focus on two key manual handling tasks } \\
\text { Aim is for learners to be successful in performing key manual } \\
\text { handling tasks before leaving classroom }\end{array}$ \\
\hline $\begin{array}{l}\text { Two: } 0 \text { - } 8 \\
\text { weeks: Working } \\
\text { independently in } \\
\text { clients' homes }\end{array}$ & $\begin{array}{l}\text { Workplace preceptor, coordinator accessed by phone or face- } \\
\text { to-face } \\
\text { Clients and/or family members may act as experts or as } \\
\text { learners at lower level depending on situation } \\
\text { Written materials - organisational policies and procedures, } \\
\text { step-by-step instructions outlining key manual handling tasks }\end{array}$ & $\begin{array}{l}\text { Experts } \\
\text { Others (e.g., } \\
\text { clients, family } \\
\text { members) at } \\
\text { lower learning } \\
\text { level } \\
\text { Working alone }\end{array}$ & $\begin{array}{l}\text { Learners aiming for increasing level of competence } \\
\text { Learners may require (or request) intervention } \\
\text { Focus on developing core manual handling knowledge } \\
\text { Aim is for learners to be successful in performing key manual } \\
\text { handling tasks in the workplace, and to be working towards } \\
\text { successful performance of related or more challenging manual } \\
\text { handling tasks }\end{array}$ \\
\hline $\begin{array}{l}\text { Three: } 8 \text { weeks: } \\
\text { Refresher } \\
\text { classroom } \\
\text { training }\end{array}$ & $\begin{array}{l}\text { Peer interaction - small group work and practical activities } \\
\text { Manual handling concepts and procedures conveyed and } \\
\text { demonstrated through the workshopping of authentic manual } \\
\text { handling scenarios encountered in preceding } 8 \text { weeks } \\
\text { Support from trainer, coordinator, experienced HCWs } \\
\text { HCWs observed by trainer for a new level of proficiency and } \\
\text { marked off against checklist }\end{array}$ & $\begin{array}{l}\text { Experts } \\
\text { HCWs at same } \\
\text { learning level }\end{array}$ & $\begin{array}{l}\text { Learners aiming for increasing level of competence } \\
\text { Learners require (or request) intervention } \\
\text { Focus on specific knowledge - manual handling } \\
\text { Aim is for learners to be successfully adapting core manual } \\
\text { handling knowledge to a range of related or more challenging } \\
\text { manual handling tasks }\end{array}$ \\
\hline $\begin{array}{l}\text { Four: } 8 \text { weeks } \\
\text { and beyond: }\end{array}$ & $\begin{array}{l}\text { Workplace preceptor, coordinator accessed by phone or face- } \\
\text { to-face }\end{array}$ & $\begin{array}{l}\text { Experts } \\
\text { Others at lower }\end{array}$ & $\begin{array}{l}\text { Learners aiming for increasing level of competence } \\
\text { Learners may require (or request) intervention }\end{array}$ \\
\hline
\end{tabular}


In summary, scaffolds for supporting new HCWs' learning included peers at the same learning level (e.g., in classroom activities), others at a lower learning level (e.g., when orientating new staff), written materials and experts. Noteworthy here, is that the scaffolds outlined in Table 1 were offered to the HCWs, however their use was not mandated, and there were no expectations about these scaffolds actually being taken up by the learners. For example, small group work was offered in the classroom as a means of augmenting learning through engagement with experts and peers, yet HCWs were not commanded be highly active in the classroom. Written materials were provided with a rationale and instructions for their use, yet it was not expected that all HCWs would read them. The intention was to offer scaffolds that would accommodate a range of individual learning styles, and acknowledge persondependence when learning in the absence of direct supervision. Each phase was designed to build levels of manual handling knowledge, so that at eight weeks post initial classroom training and beyond, HCWs would not only be able to successfully perform key manual handling tasks, but adapt the principles from these tasks to demonstrate success in performing other, more challenging tasks in their clients' homes. Consequently, with the four phases of scaffolding established, a suitable methodology was essential in order to examine how and why new HCWs engaged with the scaffolding in the relative social isolation of their clients' homes. The selected methodology and justification for same is discussed in the next section.

\section{Methodology}

This inquiry adopted a case study approach, which aims to facilitate understanding 'real' problems, improve practices, and support or influence better decision making (Merriam, 2014). The 'case' was a home care organisation whose staff provide a range of supports to clients, including manual handling activities such as people handling (e.g., showering, toileting), and non-people handling (e.g., shopping, 
housekeeping). For the purposes of this inquiry, the 'case' permitted the researcher to implement this scaffolding framework, and collect data around how it assisted new HCWs to work safely in the absence of direct supervision.

\section{Informant selection}

Low staff retention and high turnover of HCWs remains a challenge (Radford, Shacklock \& Bradley, 2015), as does the challenge of gaining access to clients' private homes for observation. Therefore, informant selection was non-random and based on convenience. While the intention was to obtain qualitative data from ten informants, seven expressed an interest and remained committed to the 12week study period. These informants comprised three males and four females varying in age, cultural background, and life (including previous education and work) experience. So, diverse gender, age and experience may have contributed to the richness of data obtained during the study. For the purposes of confidentiality and de-identification, all informants (and the organisation) were assigned pseudonyms.

\section{Data collection}

Qualitative data were obtained in the form of direct observations and semi-structured interviews. First, observation data was collected to ascertain whether or not they were enacting correct manual handling techniques. Based on these observations, interview data were then collected about how and why new workers were engaging with the scaffolding, to demonstrate these effective (or otherwise) techniques. The data were collected from each informant at two points (i.e., at 4 and12 weeks after initial classroom training). Direct observation data were collected first and, for convenience and ease of access to the informants, semi-structured interviews followed immediately afterwards. In this way too, interview questions substantiating already established facts or observations could guide some of the questioning. 
For the observations, informants were observed performing two core manual handling tasks: (a) pushing a client in their wheelchair; and (b) using a hoist to transfer a client from their bed to their wheelchair. While numerous performance criteria have been deemed to underpin manual handling 'competency' of healthcare staff over the years (e.g., Dotte, 2003; Tuohy-Main, 1994; Varcin-Coad, 2003), four criteria were selected for observation in this inquiry: (a) planning and preparing for each task - e.g., modifying the environment, setting up equipment, communicating with the client; (b) establishing a balanced body position before attempting to handle the client, and keeping the 'load' close to the body; (c) using the pelvis to power the movement rather than overworking the muscles of the back and shoulders; and (d) conscious recruitment of the core stabiliser muscles when performing manual handling tasks (Varcin-Coad, 2003). These criteria were selected on the basis of their having been observed most frequently by the researcher as both a trainer and participant in countless manual handling training sessions over a 25 -year period. Additional field notes were also made about the ways in which informants were engaging with the provided scaffolding. For example, communication books were perused for entries to see if 'experts' (e.g., workplace preceptor, service coordinator) had been requested to visit, and notes were made about the accessibility and use of written materials (e.g., policy and procedure manual) in clients' homes.

Interview questions at both points were framed to identify how and why informants were engaging with the scaffolding framework, and the kinds of learning supports that might assist them to work safely in clients' homes. Interviews were approximately one-hour in duration, and although semistructured, they remained open-ended and conversational. For example, at both data collection points, informants were asked to identify manual handling problems that they had encountered in their workplaces, and to describe the various supports they had used in selecting and enacting solutions for these problems. Other questions arose from the direct observations of informants, for example: "I 
notice that you [positive or negative observation in relation to a manual handling technique]. What made you do it this way"? A combination of both audio recording and note-taking was used to record the interview data. Some informants provided consent for a recording device to be used and felt comfortable in its presence, while others requested that the researcher take notes only during the interview. In either case, all data were stored in a well-organised, retrievable form, for analysis and reanalysis, and for access by other researchers if required.

\section{Data reduction and analysis}

The data obtained were reduced and analysed using inductive reasoning principles. Text data were read, specific segments of information were identified according to the implemented scaffolding supports, segments were summarised and arranged in general categories, which were then edited to reduce overlap and redundancy (Thomas, 2006). Observation checklists were coded according to the four pre-determined criteria, collated and presented in table form. Data were read and re-read on many occasions, with additional notes being made by the researcher. Data were searched thoroughly for certain words, phrases, patterns of behaviour, informants' ways of thinking, and accounts that were repeated or stood out (Bogdan \& Biklen, 2007). Moreover, an additional researcher was engaged to independently analyse all data as an inter-rater reliability strategy. The aim here, was to derive a set of propositions from the data about the ways in which new HCWs workers were utilising the available scaffolding to enact safe manual handling practices. So, it was anticipated that analysis of data derived from multiple sources and at two different points provides richness of data and validity to the findings of the study.

\section{Study limitations}

Limitations were considered prior to undertaking this study. Firstly, only a small number of informants were recruited. High turnover of HCWs and access to clients' homes have already been established as 
reasons for the small sample. However, Blaikie (2009) also suggests that qualitative research methods are by nature resource-intensive, and therefore smaller samples are appropriate. In view of the small sample, trialing and honing of data collection tools ensured that comprehensive data was collected from each informant.

As each case study has many unique aspects another limitation of this study may be its usefulness in generalising (Wiersma, 2009). The Australian home care sector workforce is predominantly female (AIHW, 2013), yet of the seven informants recruited for the study, four were male. These informants however, were the only ones who volunteered to participate, and who remained committed to the 12-week period. The site for study was selected as a case because its features were representative of many home care providers in Australia in terms of manual handling tasks carried out. Yet, the data were collected in natural settings (i.e., clients' private homes), where physical, social and interpersonal interactions may change at any given moment. Moreover, this data were collected by a researcher who, as a nurse educator, is very familiar with the criteria for manual handling competence and has extensive experience in supporting clients in home care settings. So, the findings here represent only one perspective, and may only be replicated by researchers who assume comparable roles.

Nonetheless, LeCompte and Goetz (1982) suggest that while findings generated from natural settings by researchers in specific social positions may be limited, they are still legitimate. The conclusions drawn here represent one reality - a "slice of data" which, when combined with the research of others in different social positions and in different settings, contribute to a holistic picture of the issue (Glaser \& Strauss, 1967, in LeCompte \& Goetz, 1982). In essence, however, the findings of this unique and small-scale study should be viewed as tentative and exploratory.

\section{Ethical considerations}


Ethical approval was granted prior to conducting the research. Information packages were provided, and consent was obtained from the home care organisation, all informants and their clients prior to collecting data for the study.

\section{Findings}

Observations and semi-structured interviews yielded data about: (a) how HCWs were engaging with the scaffolding provided; and (b) why they were engaging with specific scaffolds to achieve manual handling competency. Notably, all seven informants were observed to meet the four pre-determined criteria for manual handling competence with their clients at both four and 12 weeks. That is, when pushing wheelchairs and hoisting their clients, they were planning for each task, maintained balanced positions, initiated movement from their pelvises rather than overworking their backs and shoulders, and appeared to be recruiting core muscle strength when performing their tasks. After these observations, subsequent interviews revealed that each informant engaged with the provided scaffolding in different ways, and for different reasons, to achieve manual handling competency. Moreover, some informants reported scenarios where they had successfully managed other, more complex manual handling tasks, such as preventing a client fall, or supporting a client during a seizure.

Most of the supports were used in the first eight weeks of learning the requirements for the HCW role. In the first phase of scaffolding (i.e., initial classroom training), most use was made of HCWs at the same learning level as a means of learning safe manual handling activities, while in the second phase (i.e., on-the-job), most use was made of experts (e.g., preceptor, coordinator) and others at a lower learning level (i.e., client). In Phase Three (i.e., classroom refresher training), trainees valued the classroom activities as an opportunity to again, interact with other HCWs at the same learning level. 
In Phase Four (i.e., eight weeks and beyond) only one informant reported or was observed to use scaffolding (an expert) to enact safe practice in their clients' home.

Table 2 further explains how each informant used scaffolding to achieve manual handling competency in their clients' homes. The left-hand column identifies the informant. The centre column summarises how each informant used the scaffolding, and the right-hand column provides some sample interview responses to support how the scaffolding was used. 


\section{Table 2. How new HCWs used the scaffolding to achieve competency}

\section{How scaffolding was used Sample interview responses

Sample interview responses

Observed to be highly active in both classroom sessions e.g., very interactive with peers, led many of the group

activities

Observed to be using, and also made explicit reference to use of the training handout

Regularly accessed the coordinator as a scaffold in all

- four phases of the framework.

O Observed to be talking constantly to the client throughout the tasks, explaining each step

Observed to be highly active in the classroom sessions e.g., volunteering for single demonstrations, answering ‡ questions, sharing experiences

Made explicit reference to having the written materials on display to assist with tasks in the client's home

f Phoned the workplace preceptor regularly for support

during the first 8 weeks of the role.

Observed to be active in both classroom training

sessions, participated enthusiastically in all activities.

Called on the preceptor occasionally in the first 8 weeks.

Considered the workplace preceptor as a useful form of Support in the first 8 weeks, but not thereafter.

Considered the group work in the refresher training to be valuable.

Considered the classroom activities the most useful form of learning support.

के

Referred to the client's mother for guidance and support with correct manual handling.

"II] went through each activity at a reasonable pace, but at the same time receive[d] input from others".

"I made notes... and ... read over it a few times, just to check that I'm doing the right thing"

"he laid down and made us roll him as a client...told us whether we were doing a good job or not"

"I visualised each step as I did it"

“... I related [the classroom activities] to the job I was doing with my client...It's what saved me that time, saved the pair of us" (on successfully preventing a client from falling out of their wheelchair)

"I used...the photos and all the steps for some of the transfers, [for] the harder [tasks]"

"I... [used the workplace preceptor as] my phone-a-friend strategy...to bounce ideas off...make sure I was doing the right thing"

"[I used the activities]...to get up and move around...practice [the techniques]...have fun basically"

"[the preceptor acted as] an "official"...[to] help keep things under control ... help the workers continue to do the right thing"

"[the preceptor acted as a checkup] ... to make sure we're doing things the right way"

"[I used] the refresher training [to] sit around and nut things out"

"Learning the basics [in the classroom training], the body positioning, learning the importance of it ... practicing over and over ... really helpful...everything just happens automatically..." (on successfully supporting a client during a seizure)

"[the mother] is usually around and wants to help...she's taught me a lot" 
Table 2 suggests that $\mathrm{HCWs}$ used the social aspects within the scaffolding provided (i.e., engagement with experts, peers in the classroom) as a way of achieving manual handling competency. Nevertheless, each informant deployed the various supports in different ways, and for different purposes. Now, in Table 3, informants' rationale for the use of specific scaffolding is disclosed. The left-hand column identifies the informant and the second left column reiterates the main sources of the scaffolding used (van Lier, 1994; 2000). The next column provides some sample interview responses to support this motivation, and the right-hand column describes each HCWs' most useful scaffold, including a brief rationale for this choice. 


\begin{tabular}{|c|c|c|c|c|}
\hline & Source(s) & Rationale & Sample interview responses & Most useful scaffold \\
\hline \multirow{3}{*}{$\stackrel{\Xi}{Z}$} & \multirow{3}{*}{$\begin{array}{l}\text { HCWs at same } \\
\text { learning level; } \\
\text { 'expert' in form of } \\
\text { written materials }\end{array}$} & Sociality & $\begin{array}{l}\text { "It was great to talk to other people and get their ideas about } \\
\text { how they go about things...made me feel good about learning } \\
\text { the tasks, and doing them in clients' homes" }\end{array}$ & \multirow{3}{*}{$\begin{array}{l}\text { Main form of support used was the group work in both initial and refresher } \\
\text { classroom sessions (i.e., up to } 8 \text { weeks post initial training). Anne drew } \\
\text { upon her experiences as a mother of two daughters in learning the } \\
\text { requirements for the role. She considered that like her mothers' groups, } \\
\text { talking to others helped her to learn best. }\end{array}$} \\
\hline & & Professionalism & $\begin{array}{l}\text { "...just knowing that those supports are there, even if you don't } \\
\text { need them or use them, well that's going to help you do a good } \\
\text { job.... a safety net..." }\end{array}$ & \\
\hline & & Personal situation & $\begin{array}{l}\text { "staying fit and healthy for the children motivates me [to enact } \\
\text { safe practices]" }\end{array}$ & \\
\hline \multirow{2}{*}{ 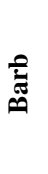 } & \multirow[t]{2}{*}{$\begin{array}{l}\text { Expert; others at } \\
\text { lower learning level }\end{array}$} & Professionalism & $\begin{array}{l}\text { "I liked seeing [the service coordinator] in the classroom and out } \\
\text { here [in the workplace]...it...makes him more approachable" }\end{array}$ & \multirow[t]{2}{*}{$\begin{array}{l}\text { Used 'experts' as a scaffold in all four phases of the framework (i.e., up to } 8 \\
\text { weeks and beyond). Barb admitted to being "nervous" about taking up the } \\
\text { HCW role, and regularly drew upon the expert for reassurance and support. }\end{array}$} \\
\hline & & Sociality & $\begin{array}{l}\text { "[the task explanations] help me relax... I can talk and visualise } \\
\text { at the same time". }\end{array}$ & \\
\hline \multirow[t]{2}{*}{ ฮี } & \multirow[t]{2}{*}{$\begin{array}{l}\text { HCWs at same } \\
\text { learning level; } \\
\text { 'expert' in form of } \\
\text { written materials }\end{array}$} & Professionalism & $\begin{array}{l}\text { "[written material] }] . . \text { show that }[\text { the organisation }] \text { have it sorted } \\
\text { and this is their way". }\end{array}$ & \multirow[t]{2}{*}{$\begin{array}{l}\text { Enjoyed the group work in both classroom training sessions as main form } \\
\text { of learning support. Dan considered himself to be a "social guy", and } \\
\text { appreciated the sociality afforded in the home care role, compared with } \\
\text { previous jobs. }\end{array}$} \\
\hline & & $\begin{array}{l}\text { Previous work } \\
\text { situation }\end{array}$ & $\begin{array}{l}\text { "... in my last job they just showed us a DVD about how to } \\
\text { lift... not even related to the work[we] were doing" }\end{array}$ & \\
\hline \multirow[b]{2}{*}{ 童 } & \multirow[t]{2}{*}{ Expert } & Professionalism & "Just knowing that [the supports] are there is a big help" & \multirow{2}{*}{$\begin{array}{l}\text { Mike reported enjoying the autonomy afforded by the home care role. Used } \\
\text { "experts' in the first } 8 \text { weeks as main form of support, but not thereafter. } \\
\text { Mike called this his "phone-a-friend" strategy. }\end{array}$} \\
\hline & & $\begin{array}{l}\text { Previous work } \\
\text { situation }\end{array}$ & $\begin{array}{l}\text { "This is so much freer than my old job...you can basically do } \\
\text { what you want...but still run things past [the preceptor] if you } \\
\text { need to" }\end{array}$ & \\
\hline \multirow{2}{*}{$\overrightarrow{\bar{z}}$} & \multirow[t]{2}{*}{$\begin{array}{l}\text { HCWs at same } \\
\text { learning level; } \\
\text { expert }\end{array}$} & $\begin{array}{l}\text { Sociality/previous } \\
\text { situation }\end{array}$ & $\begin{array}{l}\text { "I'm more used to lectures and tutorials...but [the classroom } \\
\text { activities] helped to...practice some things..." }\end{array}$ & \multirow{2}{*}{$\begin{array}{l}\text { Nat cited her experience as a university student, with more rigid learning } \\
\text { guidelines, as the rationale for using the group and practical activities in the } \\
\text { initial classroom training. She also explained that she learned best when she } \\
\text { could "move around a bit" }\end{array}$} \\
\hline & & Professionalism & $\begin{array}{l}\text { "[written materials] with the [organisational] logo all over } \\
\text { them...remind[s] everyone that we're professionals" }\end{array}$ & \\
\hline$\stackrel{\square}{\varrho}$ & $\begin{array}{l}\text { HCWs at same } \\
\text { learning level; } \\
\text { expert }\end{array}$ & $\begin{array}{l}\text { Sociality/previous } \\
\text { situation }\end{array}$ & $\begin{array}{l}\text { "[talking to other workers helps because it's]... nothing formal, } \\
\text { but we still get to have a chat about ... what's going on for us, } \\
\text { share things". }\end{array}$ & $\begin{array}{l}\text { Pete had many years of experience as a farmer before taking up the home } \\
\text { care role in a regional city. He cited this previous situation, where } \\
\text { networking with other farmers was important, as the reason for using the } \\
\text { group work in classroom his most useful scaffold. }\end{array}$ \\
\hline \multirow[t]{2}{*}{ 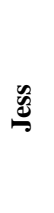 } & \multirow[t]{2}{*}{$\begin{array}{l}\text { HCWs at same } \\
\text { learning level; } \\
\text { expert }\end{array}$} & Sociality & "it was good to practice with others" & \multirow[t]{2}{*}{$\begin{array}{l}\text { Jess considered the classroom activities in initial and refresher the most } \\
\text { useful form of learning support, and used no other forms of scaffolding. } \\
\text { Jess cited her experience as a university student as the rationale for this } \\
\text { choice. }\end{array}$} \\
\hline & & Professionalism & $\begin{array}{l}\text { "[The mother] is there, she wants to help, we've got to include } \\
\text { her. This is person-centred care..." }\end{array}$ & \\
\hline
\end{tabular}


Table 3 proposes different rationales for the informants' use of scaffolding, including sociality, professionalism, and past experiences (e.g., personal and previous work situations). However, even where the scaffolds were not needed, their presence provided an implicit form of support, described by informant Anne as a 'safety net'. Consequently, the use of instructional scaffolding appears to be person-dependent when learning in the absence of direct supervision. In summary, findings presented in Tables 2 and 3 suggest that 'how' and 'why' these socially-isolated workers engaged with scaffolding differs from traditional accounts (Brown \& Palincsar, 1989; Bruner, 1975; Collins, Brown \& Newman, 1989; Wertsch, 1985; Wood et al., 1976), which forms the basis for discussion in the next section.

\section{Discussion}

An important contribution of Vygotsky's (1978) socio-cultural account of learning is the relationship proposed between interpsychological processes (i.e., those occurring between the individual and the social world) and intrapsychological outcomes (i.e., human development and learning) (Valsiner \& van de Veer, 2000). Indeed a consideration of this relationship when learning home care work may provide some clues to better understand how learning proceeds in the absence of direct supervision.

In contrast to traditional accounts of how learning and development progresses in the ZPD (Vygotsky, 1987) with the assistance of instructional scaffolding (Brown \& Palincsar, 1989; Bruner, 1975; Collins et al., 1989; Wertsch, 1985; Wood et al., 1976), the HCW informants of this inquiry engaged with the scaffolding in different ways (i.e., interpsychologically), to achieve different intrapsychological outcomes (e.g., competency in key tasks, managing complex manual handling situations). Informants were selective about the type of scaffolding used to support their learning, and 
how they used it to achieve competency. These kinds of engagements reiterate person-dependence when learning in the absence of direct supervision.

Moreover, informants reported different motivations for using the scaffolding. Sociality was a frequently reported rationale for use of various supports, and these socially-isolated workers placed a high value on opportunities to engage with others as a means of achieving workplace competency. These kinds of intrapsychological processes for learning are supported by Valsiner (2000), who suggests that much of a person's everyday learning occurs through interpreting, negotiating and buffering constant social suggestion. Professionalism was similarly reported as a reason for using scaffolding to achieve competency in the workplace, with informants suggesting that scaffolding such as written materials and the presence of a service coordinator assisted them to identify as a professional employee of the home care organisation. The use of specific scaffolding to establish worker identity may be significant here, in a role which has been historically undervalued and linked to the societal sentiments of family and love (Meagher, 2006; Stone, 2004). Other motivations, such as previous work and family experiences, were also reported as influencing the use of available learning supports.

The rationales reported here about HCWs' use of scaffolding indicate that the learning and working processes of individuals who work in the absence of direct supervision are highly dependent upon their personal epistemologies, perhaps even more so than for those who learn and work with the close guidance of others. Personal capacities and ongoing negotiations with the social world, all influence how socially-isolated workers engage in, and learn the requirements for, their occupational practice (Valsiner, 2000).

Moreover, the study findings suggest that the personal epistemologies of workers who conduct their occupational practice in the absence of direct supervision are likely to be more personally agentic (Billett et al., 2003). In engaging with the provided scaffolding, some informants considered their own 
personal circumstances (e.g., family, work). So, these workers exercised agentic action, in that they conduct their working lives and workplace learning in view of their own personal interests and goals (Billett \& Pavlova, 2005; Eteläpelto et al., 2013).

Consequently, learning safe work practices in the absence of direct supervision and support is person-dependent and may be successfully negotiated by individuals agentically. However, there are curriculum and training provisions (i.e., scaffolding) that may support learning in these circumstances. Firstly, a range of scaffolding supports should be provided in the workplaces of individuals who work in the absence of direct supervision and support. In the case of HCWs, initial and refresher classroom training, with carefully considered group and practical learning activities, access to experts (e.g., trainer, preceptor, service coordinator, client and/or family members), and written materials (e.g., classroom training handout, workplace policies and procedures, step-by-step workplace instructions for performing manual handling tasks) all appear to have been useful forms of learning support.

In considering the person-dependence of HCWs who work and learn in relative social isolation, it may be helpful to provide scaffolding without rigid stipulations about how and when it should be accessed. A recommendation from this study is to make a uniform set of supports available to HCWs in their workplaces, and provide clear explanations and guidelines for their use and access. However, beyond these guidelines, rather than following a set organisational trajectory, the worker-learners themselves should be encouraged to decide on the type and frequency of their interaction with this scaffolding, and to access or withdraw this scaffolding as required. In this way, each individual's unique and personal pathway to expertise is acknowledged.

\section{Conclusion}


In conclusion, this study proposes that for HCWs learning safe manual handling techniques in the absence of direct supervision, a pre-determined set scaffolding of supports such as group, practical classroom activities, refresher classroom training, access to experts and written materials enhanced learning and development. However, rather than following the traditional trajectory whereby the scaffolding is constructed and then removed or 'faded' by the expert as the new worker masters the work task, workers in these circumstances access provided scaffolding and mediate their own learning in personally unique ways. In conclusion, a pre-determined set of scaffolds in the workplace with which the learners can engage on an 'as needed' basis, along with clear guidelines for their use, may facilitate learning and competency in workplaces which afford little direct supervision or support.

\section{References}

Amerian, M., \& Mehri, E. (2014). Scaffolding: Definition, Steps, Features, Conditions, Tools, and Effective Considerations. Scientific Journal of Review, 3(7), 756-765.

Anderson, J. R. (1982). Acquisition of cognitive skill. Psychological Review, 89(4), 369-406.

Australian Bureau of Statistics. (2014). Employee Earnings and Hours, Australia, May 2014 (cat. no. 6306.0) published on 22nd January 2015. Retrieved from www.abs.gov.au/ausstats

Australian Institute of Health and Welfare. (2013). Australia's welfare 2013 (Cat. no. AUS 174). Canberra: AIHW.

Australian Institute of Health and Welfare. (2009). Health and community services labour force. National health labour force series number 42 (Cat. no. HWL 43). Canberra: AIHW.

Aylward, S., Stolee, P., Keat, N., \& Johncox, V. (2003). Effectiveness of continuing education in longterm care: A literature review. The Gerontologist, 43(2), 259-271.

Baldock, C., \& Mulligan, D. (2000). Restructuring and women workers in Australian home care. Resources for Feminist Research, 27(3/4), 13-27. 
Belland, B., Drake, J., \& Liu, Z. (2011). The role of affordances and motives in explaining how and why students use computer-based scaffolds. Paper presented at $11^{\text {th }}$ IEEE International Conference on Advances Learning Technologies, July $6^{\text {th }}-8^{\text {th }}$ 2011. US: University of Georgia

Bernoth, M. (2009). '... and the word was made flesh' - The impact of discourses of embodiment in promoting safe manual handling practice in aged care (Doctoral Dissertation, Monash University, Victoria, Australia).

Billett, S. (1997). Dispositions, vocational knowledge and development: Sources and consequences. Australian and New Zealand Journal of Vocational Education Research, 5(1), 1-26.

Billett, S. (2001). Knowing in practice: Re-conceptualising vocational expertise. Learning and Instruction, 11, 431-452.

Billett, S., Ehrich, L., \& Hernon-Tinning, B. (2003). Small business pedagogic practices. Journal of Vocational Education and Training, 55(2), 149-167.

Billett, S., \& Pavlova, M. (2005). Learning through working life: Self and individuals' agentic action. International Journal of Lifelong Education, 24(3), 195-211.

Blaikie, N. (2009). Designing social research. UK: Polity.

Boblett, N. (2012). Scaffolding: Defining the metaphor. Teachers College, Columbia University Working Papers in TESOL \& Applied Linguistics, 12(2), 1-16.

Boerma, W., Kroneman, M., Hutchinson, A., \& Saltman, R. B. (2013). Home care across Europe. N. Genet (Ed.). London: European Observatory on Health Systems and Policies.

Bogdan, R. C., \& Biklen, S. K. (2007). Research for education: An introduction to theories and methods. New York: Pearson.

Brown, A. L., \& Palincsar, A. S. (1989). Guided, cooperative learning and individual knowledge acquisition. In L. B. Resnick (Ed.), Knowing, learning, and instruction: Essays in honor of Robert Glaser (pp. 393-451). Hillsdale, NJ: L. Erlbaum Associates.

Bruner, J. (1975). The ontogenesis of speech acts. Journal of Child Language, 2, 1-19.

Collin, K., Paloniemi, S., Virtanen, A., \& Eteläpelto, A. (2008). Constraints and challenges on learning and construction of identities at work. Vocations and Learning, 1(3), 191-210.

Collins, A., Brown, J. S., \& Newman, S. E. (1989). Cognitive apprenticeship: Teaching the crafts of reading, writing, and mathematics. Knowing, learning, and instruction: Essays in honor of Robert Glaser, 18, 32-42. 
Daniels, H. (2016) Vygotsky and Pedagogy. NY: Routledge/Falmer.

Dotte, P. (2003). Manutention: A manual handling of loads method: A safe, efficient and comfortable approach. Sifam, France: Bi Centre for Training.

Eteläpelto, A., Vähäsantanen, K., Hökkä, P., \& Paloniemi, S. (2013). What is agency? Conceptualizing professional agency at work. Educational Research Review, 10, 45-65.

Faucett, J., Kang, T., \& Newcomer, R. (2013). Personal service assistance: Musculoskeletal disorders and injuries in consumer-directed home care. American Journal of Industrial Medicine, 56, 454-468.

Hammond, J. (Ed.) (2002). Scaffolding Teaching and Learning in Language and Literacy Education. Newtown, Australia: PETA

Health and Community Services Workforce Council. (2012, June). Industry overview: Industry skills and workforce development report for the health and community services industry. Brisbane: Health and Community Services Workforce Council Inc.

Hugo, G. (2007). Contextualising the 'crisis in aged care' in Australia: A demographic perspective. Australian Journal of Social Issues, 42(2), 169-182.

Hugo, G. (2009). Care worker migration, Australia and development. Population, Space and Place, 15(2), 189-203.

Jumaat, N. F., \& Tasir, Z. (2014, April). Instructional scaffolding in online learning environment: A meta-analysis. In Teaching and Learning in Computing and Engineering (LaTiCE), 2014 International Conference on (pp. 74-77). IEEE.

LeCompte, M. D., \& Goetz, J. P. (1982). Problems of reliability and validity in ethnographic research. Review of educational research, 52(1), 31-60.

Manthorpe, J., \& Martineau, S. (2008). Support workers: Their roles and tasks. A scoping review. University of London: Social Care Workforce Research Unit.

Markannen, P., Quinn, M., Galligan, C., Sama, S., Brouillette, N., \& O’Keyer, D. (2014).

Characterizing the nature of home care work and occupational hazards: A developmental study. American Journal of Industrial Medicine, 57, 445-457.

Martin, B., \& Healy, J. (2010, August). Who works in community services? (Report of research funded by the Community and Disability Services Ministers Advisory Council, directed by its 
Structural Issues in the Workforce Subcommittee). Flinders University, Adelaide, Australia: National Institute of Labour Studies.

Meagher, G. (2006). What can we expect from paid carers? Politics and Society, 34(1), 33-53.

Mercer, N. (1994). Neo-Vygotskian theory and classroom education. In Steirer, B \& J. Maybin (Eds.), Language, literacy and learning in educational practice (pp. 92-110). Clevedon: Multilingual Matters.

Merriam, S. B. (2014). Qualitative research: A guide to design and implementation. San Francisco, CA: John Wiley \& Sons.

Mott, S., Chau, A., \& Chan, J. (2007). Meeting the health needs of people with disability living in the community. Journal of Intellectual and Developmental Disability, 32(1), 51-53.

Nay, R., \& Garratt, S. (2002). Nursing older people. Issues and innovations. Sydney, MacLennan \& Petty.

Palesy, D. (2015). 'Learning occupational practice in the absence of expert guidance: A case study of in-home disability support workers' (Doctoral Dissertation, Griffith University, Queensland, Australia).

Perkins, D., Jay, E., \& Tishman, S. (1993). Beyond abilities: A dispositional theory of thinking. Merrill-Palmer Quarterly, 39(1), 1-21.

Radford, K., Shacklock, K., \& Bradley, G. (2015). Personal care workers in Australian aged care: retention and turnover intentions. Journal of nursing management, 23(5), 557-566.

Ryle, G. (1949). The concept of mind. London: Hutchinson University Library.

Salyers, V., Carter, L., Cairns, S., \& Durrer, L. (2014). The use of scaffolding and interactive learning strategies in online courses for working nurses: Implications for adult and online education. The Canadian Journal of University Continuing Education, 40(1), 1 - 19.

Sharma, P., \& Hannafin, M. (2007). Scaffolding in technology-enhanced learning environments. Interactive Learning Environments, 15, 1, 27-46.

Somerville, M. (2006). Becoming - worker: Vocational training for workers in aged care. Journal of Vocational Education and Training, 58(4), 471-481.

Stone, R. I. (2004). The direct care worker: The third rail of home care policy. Annu. Rev. Public Health, 25, 521-537. 
Stone, R., Sutton, J., Bryant, N., Adams, A., \& Squillace, M. (2013). The home health workforce, a distinction between worker categories. Home Health Services Quarterly, 32(4), 218-233.

Thomas, D. (2006). A general inductive approach for analyzing qualitative evaluation data. American Journal of Evaluation, 27(3), 237-246.

Tuohy-Main, K. (1994). A manual of handling people. Adelaide: Helios Art \& Book Co.

Van Lier, L. (1994). Language awareness, contingency and interaction. AILA Review, 11, 69-82

Van Lier, L. (2000). From input to affordance: social interactive learning from an ecological perspective. In Lantolf, J.P. (Ed.). Sociocultural theory and second language learning (pp 245260). New York: Oxford University Press.

Van Lier, L. (2008). Agency in the classroom. In Lantolf, J.P \& Poehner, M.E. (Eds.). Sociocultural theory and the teaching of second languages (pp 163-186). London: Equinox.

Valsiner, J. (2000). Culture and human development. London: Sage.

Valsiner, J., \& van der Veer, R. (2000). The social mind: The construction of an idea. Cambridge, UK: Cambridge University Press.

Varcin-Coad, L. (2003). Manual handling for carers of people : Freestyle technique \& sit to stand: video booklet including competency based assessment tools. Gold Coast, Queensland: Varcin \& Associates.

Verenikina, I. (2008). Scaffolding and learning: its role in nurturing new learners. In Kell, P, Vialle, W, Konza, D \& Vogl, G. (Eds), Learning and the learner: exploring learning for new times, (pp. 161 - 180) University of Wollongong.

Vygotsky, L.S. (1978). Mind in society: The development of higher psychological processes. Cambridge: Harvard University Press.

Walqui, A. (2006). Scaffolding instruction for English language learners. The International Journal of Bilingual Education and Bilingualism, 9, 159-180.

Wertsch, J. V. (Ed). (1985). Culture, communication and cognition: Vygotskian perspectives. Cambridge: Cambridge University Press.

Wertsch, J. W. (1991). A sociocultural approach to socially shared cognition. In L. B. Resnick, J. M. Levine, \& S. D. Teasley (Eds.), Perspectives on socially shared cognition (pp. 85-100). Washington, DC: American Psychological Association.

Wiersma, W. (2009). Research methods in education. New Delhi: Pearson Education India. 
Wood, D., Bruner, J., \& Ross, G. (1976). The role of tutoring in problem solving. Journal of Child Psychology and Psychiatry and Allied Disciplines, 17, 89-100.

Yates, G. C. R., \& Chandler, M. (1991). The cognitive psychology of knowledge: Basic research findings and educational implications. Australian Journal of Education, 35(2), 131-153. 